\title{
Blood transfusion practices in obstetrics and gynecology: study of indications as a measure to prevent maternal morbidity and mortality
}

\author{
Neeta Chaudhary ${ }^{1}$, Natasha Tyagi ${ }^{2}$, Smita Tyagi $^{1 *}$, G. S. Manchanda ${ }^{1}$, Malvika ${ }^{1}$
}

\begin{abstract}
${ }^{1}$ Department of Obstetrics and Gynecology, Muzaffarnagar Medical College, Muzaffarnafar, UP, India
${ }^{2}$ Department of Obstetrics and Gynecology, University College of Medical Sciences, New Delhi, India
\end{abstract}

\author{
Received: 22 December 2020 \\ Revised: 08 February 2021 \\ Accepted: 09 February 2021 \\ *Correspondence: \\ Dr. Smita Tyagi, \\ E-mail: drsmitatyagi58@gmail.com
}

Copyright: (c) the author(s), publisher and licensee Medip Academy. This is an open-access article distributed under the terms of the Creative Commons Attribution Non-Commercial License, which permits unrestricted non-commercial use, distribution, and reproduction in any medium, provided the original work is properly cited.

\begin{abstract}
Background: This is a study of rational use of blood transfusion in a tertiary care center. So, this study was done to find out the indications of blood transfusion in department of obstetrics and gynaecology and measures to minimize the requirement of blood transfusion to reduce maternal mortality and morbidity.

Methods: This is a retrospective study in department of obstetrics and gynaecologyin Muzaffarnagar Medical College, Muzaffarnagar, U.P. in collaboration with the department of pathology including blood bank for the duration of 1 year i.e. 1st January, 2017 to $31^{\text {st }}$ December, 2017. Total transfusions in 1 year were 706 of which 406 were in obstetrics and 300 were in gynecology.

Results: In our study maximum $16.20 \%$ blood transfusions were given during cesarean section in third trimester in unbooked cases who came with severe anemia in labour. Others were APH (12\%) and abortions (13.05\%). This shows that anemia is still a major cause of maternal mortality and morbidity in India. In Gynecological cases blood transfusion was more in third parity and above indicating that perimenopausal women were also more susceptible for anemia due to disease of perimenopausal age group like AUB and fibroid.

Conclusions: Maximum number of transfusions specially PRBC in obstetrics were of moderate to severe anemia, mainly to the patients who were term or in labor and of high-risk pregnancies, who were unbooked with no antenatal care. In Gynecology cases, blood transfusion was of perimenopausal or menopausal group with moderate anemia. This comes to the conclusion that all preventive measures should be taken in females from womb to tomb to correct anemia and this will indirectly help to prevent maternal and perinatal morbidity and mortality.
\end{abstract}

Keywords: Blood transfusion, Blood components, Indication of blood transfusion

\section{INTRODUCTION}

Blood transfusion is an important part of patient management in Obstetrics and Gynecology. There is a need to periodically assess the blood transfusion practices to identify the areas of improvement. Blood is a precious product as it needs to be obtained from human beings and is a costly product. It needs to be used judiciously. Prescription of blood is usually dependent on clinician's assessment of blood loss and patient's condition. In the modern era of evidence - based medicine, there is a need to periodically review blood transfusion practices at a tertiary care centers. The Royal College of Obstetricians and Gynecologists (RCOG) has recently produced guidelines for the appropriate use of blood product that neither compromises obstetrics patients nor expose them to unnecessary risk. ${ }^{1-3}$

Long term complications of allogenic transfusion have a big impact, as the obstetric patients are young. Complications are rarely discussed outside the world of blood banking but would include transfusion related 
immune suppression, microchimerism, alloimmunization and possibly an increase in the risk of transfusion related diseases. $^{4}$

Epidemiological data regarding blood transfusion is useful in that it is an important first step in answering the question regarding how much blood is transfused, gross data and who is receiving the blood (description of the recipient population).

Addressing the concern as to why blood is transfused in various clinical situations is by far the most challenging question. Answering this question has the potential to impact substantially the other two question and will be the only way to effectively control blood usage. ${ }^{3}$

The present study has been carried out to understand the practice of blood transfusion in department of obstetrics and gynecology in Muzaffernagar Medical College, U.P. It will help in the formulation of future departmental blood transfusion guidelines (over a period 2010 to 2017).

It was also seen that maximum units of blood transfusions occurred in department of Obstetrics and Gynecology in 7 years as compared to the other departments. So we also tried to find its causes, whether it is due to lack of education in patients, poverty or failure in application of family welfare programs and what can be done to prevent it.

Appropriate and rational use of blood components is essential for ensuring availability for the needy as well as preventing risks of transfusion transmitted disease and saving resources.

Rational use means providing the blood or it's product in the right quantity to right patient and at the right time bridging demand, and supply gap. The safety, adequacy and effectiveness can only be achieved if unnecessary transfusion can be prevented. Further risk can be reduced, but cannot be eliminated completely.

Aims and objectives of the study are to study the indications of blood transfusion and measure to minimise the requirement of blood transfusion to reduce maternal mortality and morbidity. To study the use of blood components in obstetrics and gynaecology.

\section{METHODS}

The present study was done in the department of Obstetrics and Gynecology in collaboration with the department of Pathology (including Blood Bank) at tertiary care centre from $1^{\text {st }}$ January, 2017 to $31^{\text {st }}$ December, 2017.

Retrospective analysis of one year data available in the blood transfusion register was done to study blood bank practices.

\section{Selection criteria of the patient}

All the patients who received blood transfusion in Obstetrics and Gynecology were studied.

In Obstetrics, history of the patient was taken with importance to the obstetric history, general and obstetrics examination. Investigation were sent and causes of blood transfusion and units to be transfused was noted. It was also noted, whether whole blood or components of blood was transfused (PRBC, FFP and platelets). Blood transfusion was monitored and complications were noted.

In Gynecology, patients history was noted, general and gynecological examination was done and cause of blood transfusion, units to be transfused and components of blood to be transfused were noted.

In the end conclusion was drawn, about the cause of blood transfusion in department of obstetrics and gynecology and how we can decrease the usage of blood transfusions and thus decrease maternal and fetal mortality and morbidity.

\section{RESULTS}

Total number of blood transfusion given to the women admitted in the department of Obstetrics and Gynecology over a period of one year were 706 of which 406 transfusions were given to the obstetrics patients whereas 300 transfusions were given to the gynecology patients.

Table 1: Blood supply report of mmc (from 2010 to 2017).

\begin{tabular}{|llll|}
\hline & $\begin{array}{l}\text { Total units of } \\
\text { blood received } \\
\text { in obstetrics } \\
\text { and } \\
\text { Yynaecology }\end{array}$ & $\begin{array}{l}\text { Total units } \\
\text { of blood } \\
\text { transfusion } \\
\text { in MMC }\end{array}$ & $\begin{array}{l}\text { Percentage } \\
\text { of blood } \\
\text { transfusion } \\
\text { in obstetrics } \\
\text { and } \\
\text { gynaecology } \\
\text { department }\end{array}$ \\
\hline $\mathbf{2 0 1 0}$ & 113 & 889 & 12.70 \\
\hline $\mathbf{2 0 1 1}$ & 120 & 813 & 14.70 \\
\hline $\mathbf{2 0 1 2}$ & 257 & 1240 & 20.70 \\
\hline $\mathbf{2 0 1 3}$ & 374 & 2062 & 18.10 \\
\hline $\mathbf{2 0 1 4}$ & 419 & 3117 & 13.40 \\
\hline $\mathbf{2 0 1 5}$ & 347 & 3269 & 10.61 \\
\hline $\mathbf{2 0 1 6}$ & 444 & 3803 & 11.60 \\
\hline $\mathbf{2 0 1 7}$ & 706 & 5114 & 13.80 \\
\hline
\end{tabular}

The above data shows blood supply report of blood bank of tertiary medical college in obstetrics and gynecology department verses other departments of the college from the year 2010 to 2017. It shows that in the year 2010 it was 113 units $(12.70 \%)$ of the total blood supply of 889 units and it is gradually increasing in the year 2017 to 706 units $(13.80 \%)$ of the total blood supply 5114 units. 
We will study and analyze the transfusion of blood and its components in department of obstetrics and gynecology in 2017 to know the indications of blood transfusion and blood components and hence reduce unnecessary complications and maternal morbidity and mortality.

From 2012 sanction was obtained for blood components as appropriate selection of blood components prevents unnecessary transfusions, minimizes the risk of adverse transfusion events and improves management of limited blood bank resources and decrease the cost of health care.

Table 2: Monthly blood supply for year 2017.

\begin{tabular}{|lll|}
\hline Month & $\begin{array}{l}\text { Total units of blood } \\
\text { received in obstetrics and } \\
\text { gynaecology department }\end{array}$ & Percent \\
\hline January & 58 & 8.21 \\
\hline February & 49 & 6.90 \\
\hline March & 63 & 8.90 \\
\hline April & 26 & 3.60 \\
\hline May & 76 & 10.60 \\
\hline June & 65 & 9.20 \\
\hline July & 64 & 9.00 \\
\hline August & 68 & 9.60 \\
\hline September & 57 & 8.07 \\
\hline October & 64 & 9.00 \\
\hline November & 70 & 11.10 \\
\hline December & 35 & 4.90 \\
\hline Total & 706 & \\
\hline
\end{tabular}

Total Blood Transfusions in department - 706 units. Number of Obstetrics transfusions - 406 units. Number of Gynecology transfusions - 300 units.

Above data shows the month wise distribution of transfusion of blood. It was maximum in November i.e. 79 units $(11.10 \%)$ and minimum in month of April i.e. 26 units $(3.60 \%)$. Total 706 units was transfused in year 2017.

Out of 706 units in 2017, 406 units were transfused in Obstetrics and 300 units in Gynecology. It also shows that blood transfusion units were more in Obstetrics indicating the need of improving antenatal, natal and post natal services.

\section{Demographic characteristics}

Above data shows the age distribution. Maximum 257 units $(63.30 \%)$ in obstetrics were transfused in age group 21 - 30 years indicating that this reproductive age group needs most transfusions. In gynecology maximum 77 units $(25.60 \%)$ were transfused in age group $41-50$ years indicating that perimenopausal age group needs most transfusion.
Table 3: Age distribution of patients receiving blood transfusion.

\begin{tabular}{|lllll|}
\hline $\begin{array}{l}\text { Age } \\
\text { (years) }\end{array}$ & Obstetrics & Gynaecology \\
\hline $\mathbf{1 5}-\mathbf{2 0}$ & 37 & 9.11 & 40 & 13.30 \\
\hline $\mathbf{2 1}-\mathbf{3 0}$ & 257 & 63.30 & 42 & 14.00 \\
\hline $\mathbf{3 1}-\mathbf{4 0}$ & 75 & 18.47 & 70 & 23.30 \\
\hline $\mathbf{4 1}-\mathbf{5 0}$ & 37 & 9.11 & 77 & 25.60 \\
\hline $\mathbf{5 1}-\mathbf{6 0}$ & 0 & 0 & 51 & 17.00 \\
\hline $\mathbf{6 1}-\mathbf{7 0}$ & 0 & 0 & 20 & 0.00 \\
\hline Total & 406 & & 300 & \\
\hline
\end{tabular}

Table 4: Distribution of gravidity in obstetrics in 2017.

\begin{tabular}{|lll|}
\hline $\begin{array}{l}\text { Gravida in } \\
\text { obstetrics }\end{array}$ & Number of patients & Percent \\
\hline Primigravida & 93 & 22.90 \\
\hline Multigravida & 313 & 77.09 \\
\hline
\end{tabular}

Above data shows maximum blood transfusion was of 93 units $(22.90 \%)$ in primigravida and 313 units $(77.09 \%)$ in multigravida patients. It is surprising to observe that $22.90 \%$ of primigravida require blood transfusion and further study shows that anaemia is more common in rural areas and the school going girls showing the need to improve application of government programmes of distributing Iron and Folic Acid in the society in preschool and school going girls as it would help to decrease maternal mortality and morbidity.

Table 5: Parity in gynecology.

\begin{tabular}{|lll|}
\hline Parity & Number of patients & Percent \\
\hline Nullipara & 46 & 15.30 \\
\hline One & 33 & 11.00 \\
\hline Two & 60 & 20.00 \\
\hline Three & 88 & 29.30 \\
\hline Four and above & 73 & 24.30 \\
\hline
\end{tabular}

Above data shows that blood transfusion was maximum in third para and above i.e 88 units (29.30\%). In Gynecological cases blood transfusion was more in third parity and above indicating that perimenopausal women were also more susceptible for anaemia due to diseases of perimenopausal age group like AUB and fibroid.

Table 6: Distribution of obstetrics cases receiving blood transfusion as per Period of gestation.

\begin{tabular}{|lll|}
\hline $\begin{array}{l}\text { Period of } \\
\text { Gestation }\end{array}$ & Number of patients & Percent \\
\hline $\mathbf{0}-\mathbf{1 3}$ weeks & 53 & 13.00 \\
\hline $\mathbf{1 3}-\mathbf{2 6}$ weeks & 55 & 13.50 \\
\hline $\mathbf{2 6}-\mathbf{3 6}$ weeks & 113 & 27.80 \\
\hline$>\mathbf{3 6}$ weeks & 185 & 45.56 \\
\hline Total & 406 & \\
\hline
\end{tabular}


Above data shows that blood transfusion in obstetrics cases according to period of gestation. It shows that maximum blood transfusion 185 units $(45.56 \%)$ occurred in the period of gestation of 36 weeks and above. It is a very serious situation as it indicates that there was no proper antenatal care in these patients and this is the time when delivery has to take place and anaemia is most important indirect cause of maternal mortality and it has to be treated and prevented at any cost to decrease maternal mortality and morbidity.

Table 7: Haemoglobin level at the time of admission of patients in gynecology and obstetrics.

\begin{tabular}{|c|c|c|c|c|}
\hline Category & \multicolumn{2}{|c|}{ Obstetrics cases } & \multicolumn{2}{|c|}{ Gynaecology cases } \\
\hline $\begin{array}{l}\text { Hb gm\% } \\
\text { level }\end{array}$ & $\begin{array}{l}\text { No. of } \\
\text { patients }\end{array}$ & Percent & $\begin{array}{l}\text { No. of } \\
\text { patients }\end{array}$ & Percent \\
\hline $8-10.9$ & 64 & 9.06 & 106 & 24.70 \\
\hline $6-7.9$ & 191 & 24.07 & 116 & 35.33 \\
\hline $4-5.9$ & 86 & 21.18 & 44 & 14.66 \\
\hline $\begin{array}{l}\text { Very } \\
\text { severe }<4\end{array}$ & 65 & 16.00 & 34 & 13.33 \\
\hline Total & 406 & & 300 & \\
\hline
\end{tabular}

Above data shows $\mathrm{Hb} \%$ level at the time of admission. Maximum cases were of moderate anaemia in both obstetrics and gynecology.

In Obstetrics, 191 cases (24.07\%) and in Gynecology, 116 cases $(35.33 \%)$ were of moderate anaemia.

Table 8: Indication of blood transfusion in obstetrics in MMC in 2017.

\begin{tabular}{|lll|}
\hline Indication (Obstetrics) & Cases (406) & Percent \\
\hline $\begin{array}{l}\text { 1st } \text { Trimester } \\
\text { Haemorrhage }\end{array}$ & 28 & 6.80 \\
\hline Rupture uterus & 28 & 6.80 \\
\hline APH & 49 & 12.00 \\
\hline Ectopic pregnancy & 30 & 7.30 \\
\hline PPH & 30 & 7.30 \\
\hline P. Sepsis & 30 & 7.30 \\
\hline L.S.C.S. & 66 & 16.2 \\
\hline $\begin{array}{l}\text { Pre - eclampsia } \\
\text { Toxaemia }\end{array}$ & 30 & 7.3 \\
\hline Jaundice & 28 & 6.8 \\
\hline Molar pregnancy & 28 & 6.8 \\
\hline Abortion & 53 & 13.05 \\
\hline Haematoma & 6 & 1.40 \\
\hline
\end{tabular}

Above data shows indications of blood transfusion in Obstetrics. Maximum 66 cases (16.20\%) were given blood transfusion during caesarean section followed by APH 49 cases (12\%) and abortion 53 cases (13.05\%). This shows that these women were mostly unbooked and were anaemic even during the third trimester and hemorrhage is still the major cause of maternal mortality and all measures should be done to prevent and treat it so as to decrease maternal mortality.

Table 9: Indication of blood transfusion in gynecology.

\begin{tabular}{|lll|}
\hline Indication (gynaecology) & Cases (300) & Percent \\
\hline Pre Operative & 130 & 32.01 \\
\hline Post Operative & 39 & 13.00 \\
\hline AUB & 33 & 13.00 \\
\hline Ovarian Tumour & 22 & 7.30 \\
\hline Infertility & 15 & 5.00 \\
\hline $\begin{array}{l}\text { Post Menopausal } \\
\text { Bleeding }\end{array}$ & 14 & 4.60 \\
\hline Pyometra & 14 & 4.6 \\
\hline Puberty Menorrhagia & 27 & 9.00 \\
\hline Genital Malignancy & 6 & 2.00 \\
\hline
\end{tabular}

Maximum of 130 cases $(32.01 \%)$ were transfused blood pre operatively in gynaecology showing that most of the women were anaemic during the preoperative period due to diseases like AUB and fibroid and needed blood transfusion so that they could be operated safely.

Table 10: Distribution of blood transfused as whole blood or blood component.

\begin{tabular}{|c|c|c|c|c|c|c|}
\hline \multirow{2}{*}{$\begin{array}{l}\text { Type of } \\
\text { blood } \\
\text { transfusi } \\
\text { on }\end{array}$} & \multicolumn{2}{|c|}{$\begin{array}{l}\text { Obstetrics } \\
\text { cases }\end{array}$} & \multicolumn{2}{|c|}{$\begin{array}{l}\text { Gynaeco- } \\
\text { logy cases }\end{array}$} & \multirow{2}{*}{ Total } & \multirow{2}{*}{$\%$} \\
\hline & $\begin{array}{l}\text { Uni } \\
\text { ts }\end{array}$ & $\%$ & $\begin{array}{l}\text { Unit } \\
\text { s }\end{array}$ & $\%$ & & \\
\hline $\begin{array}{l}\text { Whole } \\
\text { blood }\end{array}$ & 6 & 2.00 & 0 & 0 & 6 & 0.84 \\
\hline $\begin{array}{l}\text { Packed } \\
\text { red blood } \\
\text { cells }\end{array}$ & 388 & 95.56 & 300 & $\begin{array}{l}10 \\
0\end{array}$ & 688 & 97.45 \\
\hline $\begin{array}{l}\text { Platelet } \\
\text { (jumbo } \\
\text { pack) }\end{array}$ & 5 & 1.20 & 0 & 0 & 5 & 0.70 \\
\hline $\begin{array}{l}\text { Fresh } \\
\text { frozen } \\
\text { plasma }\end{array}$ & 7 & 1.72 & 0 & 0 & 7 & 0.99 \\
\hline Total & 406 & & 300 & & 706 & \\
\hline
\end{tabular}

Above data shows the distribution of blood transfusion as whole blood or blood component. It shows that components mainly PRBC 388 units (95.56\%) are more prevalent than whole blood as it has its own advantages like

It maintains $\mathrm{O} 2$ carrying capacity.

It is safe as it avoids transfusion reaction, avoid transmission of infections and avoids fluid overload.

Whole blood was given only in Obstetrics cases of Acute blood loss ( $>30 \%$ of Blood Volume) as in cases of severe 
PPH and during L.S.C.S. in unbooked cases of placenta previa with placenta accrete.

Table 11: Number of blood transfusion units received by individual subjects.

\begin{tabular}{|c|c|c|c|c|}
\hline \multirow{2}{*}{$\begin{array}{l}\text { Units } \\
\text { of } \\
\text { blood }\end{array}$} & \multicolumn{2}{|c|}{$\begin{array}{l}\text { Blood transfusion } \\
\text { (obstetrics) }\end{array}$} & \multicolumn{2}{|c|}{$\begin{array}{l}\text { Blood transfusion } \\
\text { (gynaecology) }\end{array}$} \\
\hline & Cases & Percent & Cases & Percent \\
\hline 1 & 200 & 49.26 & 161 & 53.60 \\
\hline 2 & 145 & 35.71 & 98 & 32.60 \\
\hline 3 & 37 & 9.11 & 29 & 9.66 \\
\hline 4 & 18 & 4.40 & 9 & 3.00 \\
\hline 5 & 5 & 1.23 & 2 & 0.66 \\
\hline$>5$ & 1 & 0.24 & 1 & 0.33 \\
\hline Total & 406 & & 300 & \\
\hline
\end{tabular}

Above data shows that one unit of Blood Transfusion was given in 200 patients $(49.26 \%)$ in Obstetrics and 161 patients $(53.60 \%)$ in Gynecology and more than 5 units were given in 1 case $(0.24 \%)$ of Obstetrics and 1 case $(0.33 \%)$ of Gynecology.

\section{DISCUSSION}

This study was done for one year from 1st January to 31st December, 2017 in a tertiary hospital and total 706 units was transfused in Obstetrics and Gynecology Department which is $13.8 \%$ of the total blood transfusion of the whole hospital.

Age group of blood transfusion was from 15 years to 70 years. $71.0 \%$ was transfused in Multigravida in obstetrics and $29.3 \%$ in 3rd para in gynecology. Similarly maximum blood transfusion were in the gestational age of 36 weeks and above (45.5\%) Chawla S et. al. In 2018 also studied blood transfusion practices in obstetrics and reported that women were from different age group and were a mix of primigravida and multigravida. ${ }^{5}$ They also reported maximum transfusion in gestational age of 3140 weeks.

KawthalKar et. al. in 2015also studied 6\% transfusion in obstetrics and gynaecology. ${ }^{6}$ It was 1008 units in one year with 632 units in obstetrics patients and 376 units in gynecology patients. It is similar to our study with 706 units in one year with 406 units in obstetrics and 300 units in gynecology.

During the study period, the incidence of blood product transfusion for Obstetric patients in our institution was 185 units $(45.56 \%)$ occurred in the period of gestation of 36 weeks and above.

It is a very serious situation as it indicates that there was no proper antenatal care in these patients and this is the time when delivery has to take place and anaemia is most important indirect cause of maternal mortality and it has to be treated and prevented at any cost to decrease maternal mortality and morbidity. Which was similar to previously reported studies $0.3-1 \%$ by James in Europe and Japanese Center. ${ }^{7,8}$

Moderate and severe anemia was the most common cause of PRBC transfusion (96.55\%) in obstetrics and gynecology. It can be correlated to the fact that maximum percent case of anemia came in third trimester and were unbooked cases and illiterate patients of rural area. Most of them were laborer and $12 \%$ of cases were of APH where emergency blood transfusion of one unit of PRBC $(53.6 \%)$ and two unit $(32.6 \%)$ of PRBC is given as a life saving measure during caesarean or normal delivery and in most cases of APH. All these things are correlated.

In our study unbooked case with no antenatal care came in labor with moderate to severe anemia and one or two units of blood become necessary to save the patient and prevent maternal and fetal mortality and morbidity.

Gupta A et. al. in 2018 also studied transfusion audit and reported that appropriate selection of blood components are necessary to minimize the risk of adverse transfusion events and $84.57 \%$ were of PRBC which is in accordance with our study. ${ }^{9}$ As per WHO, the preparation of blood components allows a single blood donation to provide treatment for two or three patients and also avoids the transfusion of elements of the whole blood that the patients may require. ${ }^{12}$

Latachabra S, et. al. advocates blood transfusion in moderate to severe anemia irrespective of symptoms nearing the date of birth. ${ }^{10}$ In our study also maximum transfusion of PRBC (45.5\%) was in gestational age of 36 weeks and more and during labor with moderate to severe anemia.

Kawthal et. al. also reported in 2015 that maximum unit $(41.4 \%)$ were transfused at term and $35.5 \%$ transfusion were for anemia and $36.2 \%$ were for obstetrics hemorrhage which is in accordance with our study. ${ }^{6}$ In our study in gynecological cases maximum number of transfusion were for preoperative patients (46.33\%) and of AUB (13\%). Kawthal et. al. in 2015 also reported that majority of patients in gynecology $(55.1 \%)$ received transfusion for preoperative correction of anaemia in abnormal uterine bleeding. ${ }^{6}$

James in Europe and a Japanese center told that the incidence of blood transfusion was $0.3-1 \%$ and $1.3 \%$ respectively which is very less than our study which is $13.8 \%$. It may be due to the fact that India is a developing country needing more blood transfusions to save the patient. $^{7,8}$

In our study whole blood was transfused in 6 cases $(2 \%)$ in obstetrics and none in gynecology and only in cases of acute blood loss of $>30 \%$ blood volume and patient is in shock. 
Gupta et. al. in 2013 also reported that promoting component therapy not only brings down the requirement of whole blood but also ensures optimum use of blood. ${ }^{11}$ They reported that there was significant decline in the use of whole blood from $36.4 \%$ in the year 2003 to $15.6 \%$ in the year 2010. Our study also has similar trend and is due to increased awareness about component use for the management of obstetrics and gynecology patients.

As per WHO the preparation of blood components allows a single blood donation to provide treatment for two or three patients and also avoids the transfusion of elements of the whole blood that the patient may not require. ${ }^{12}$ Packed Red Cell transfusions should be preferred in these cases.

\section{CONCLUSION}

Maximum number of transfusions specially PRBC in obstetrics were given in moderate to severe anemia, mainly to the patients who were term or in labour and of high-risk pregnancies, who were unbooked with no antenatal care, especially from rural areas because our hospital mainly caters to rural areas.

In Gynecology cases, blood transfusion were of perimenopausal or menopausal group with moderate anemia.

This comes to the conclusion that all preventive measures should be taken in females from womb to tomb to correct anemia and this will indirectly help to prevent maternal and perinatal morbidity and mortality.

Funding: No funding sources Conflict of interest: None declared

Ethical approval: The study was approved by the Institutional Ethics Committee

\section{REFERENCES}

1. Royal College of Obstetrician and GynecologistsBlood transfusion in obstetrician. Green Top Guideline No. 47; 2015.

2. Parker J, Thompson J, Stanwarth S. A retrospective one year single centre survey of red cell transfusion.
International journal of obstetrics anaesthesia. 2009; 18:309-13.

3. Clark V, Waters JH. Editorial- Blood transfusion; more is not necessarily better. International Journal of obstetrics Anaesthesia. 2009;18:299-301.

4. Sweeney JD. Can physician prescribing pattern really be influenced and are there obstacles? International journal of obstetrics anaesthesia. 2009:39(2):139-44.

5. Chawla S, Bal MHK, Vardhan BS, Jose CT, Sahoo I. Blood transfusion practices in obstetrics: a prospective observational study, Dept of obstetrics and gynaecology in Armed forces medical college, Pune. J Obstetr Gynaecol. 2018;68(3):204-7.

6. Kawthalkar A, Kose V, Joshi S, Bhalerao A, Kumare B, Somalwar S. Blood transfusion in obstetrics and gynaecology. A retrospective analysis (original research) panacea. J Medic Sci. 2015:5(3):109-12.

7. Carson JL, Hill S, Carless P. Transfusion triggers: a systematic review of the literature. Transfus Med Rev. 2002;16(3):187-99.

8. Matsunaga S, Seki $\mathrm{H}$, Ono, Y. A retrospective analysis of the transfusion management for obstetric haemorrhage in a Japanese Obstetric Center. ISRN Obst Gynecol. 2012:854064.

9. Gupta A, Manchanda GS, Sharma P, Sharma VK. Transfusion audit in a tertiary care hospital (original article) Department of Pathology, Muzaffarnagar Medical College and hospital, Muaffarnagar. Indian J Basic Applied Medic Res. 2018;8(1):467-72.

10. Chabra SL, Gyal AN. Rationale use of blood and its components in obstetric- gynaecological practice. J Mahatma Gandhi Institute of Medic Sci. 2014;19(2).

11. Snehalata C. Gupta and Pratima N Patil. Blood transfusion practice in obstetrics and Gynaecology; Impact of Educational programes to create awareness for judicious use of blood components. J Hematol Blood Transfusion. 2014;30(3):175-9.

12. World Health Organisation Blood Transfusion Safety Geneva. The clinical use of blood Handbook.

Cite this article as: Chaudhary N, Tyagi N, Tyagi S, Manchanda GS, Malvika. Blood transfusion practices in obstetrics and gynecology: study of indications as a measure to prevent maternal morbidity and mortality. Int J Reprod Contracept Obstet Gynecol 2021;10:999-1004. 